\title{
IMPLEMENTASI UNDANG-UNDANG NOMOR 12 TAHUN 2011 PADA PENYUSUNAN PERATURAN DESA DI KABUPATEN INDRAMAYU
}

\author{
Rasji $^{1}$, Gunardi ${ }^{2}$ \\ ${ }^{1}$ Fakultas Hukum, Universitas Tarumanagara, Jakarta \\ Email: rasji@fh.untar.ac.id \\ ${ }^{2}$ Fakultas Hukum, Universitas Tarumanagara, Jakarta \\ Email: gunardi@fh.untar.ac.id
}

Masuk : 10-10-2020 revisi: 27-10-2020, diterima untuk diterbitkan : 31-10-2020

\begin{abstract}
Indonesia has enacted Law Number 12 Year 2011 concerning the Formation of Legislation. Village regulation is one of the laws and regulations established by the village and its formation must refer to this law. How is the implementation of Law Number 12 Year 2011 in the practice of forming village regulations in Indramayu Regency? What are the obstacles in implementing Law No.12 of 2011 on the formation of village regulations? This problem has been investigated using empirical research methods. The aim is to determine the implementation of Law No.12 of 2011 on the formation of village regulations. The results of this study indicate that Law Number 12 of 2011 has not been implemented properly in the formation of village regulations. The obstacle is that village government officials do not have knowledge of the formation of village regulations.
\end{abstract}

Keywords: Law Number 12 Year 2011, implementation, village regulations

\begin{abstract}
ABSTRAK
Indonesia telah menetapkan Undang-Undang Nomor 12 Tahun 2011 tentang Pembentukan Peraturan Perundangundangan. Peraturan desa adalah salah satu peraturan perundang-undangan yang dibentuk oleh desa dan pembentukannya harus mengacu pada undang-undang tersebut. Bagaimana implementasi Undang-Undang Nomor 12 Tahun 2011 pada praktik pembentukan peraturan desa di Kabupaten Indramayu? Apa yang menjadi kendala dalam implementasi Undang-Undang Nomor 12 Tahun 2011 pada pembentukan peraturan desa? Permasalahan tersebut telah diteliti dengan menggunakan metode penelitian empiris. Tujuannya adalah untuk mengetahui implementasi Undang-Undang Nomor 12 Tahun 2011 terhadap pembentukan peraturan desa. Hasil penelitian ini menunjukan Undang-Undang Nomor 12 tahun 2011 belum diimplementasikan dengan baik pada pembentukan peraturan desa. Kendalanya adalah aparatur pemerintah desa belum memiliki pengetahuan tentang pembentukan peraturan desa.
\end{abstract}

Kata Kunci: Undang-Undang Nomor 12 Tahun 2011, implementasi, peraturan desa.

\section{PENDAHULUAN}

Negara Indonesia memiliki wilayah luas dan urusan pemerintahan yang kompleks. Pasal 18 Undang-Undang Dasar Negara Kesatuan Republik Indonesia Tahun 1945 (UUD 1945) menyatakan bahwa wilayah Negara Kesatuan Republik Indonesia dibagi atas daerah-daerah provinsi. Daerah provinsi dibagi atas daerah kabupaten dan daerah kota. Setiap daerah kabupaten atau daerah kota dibagi lagi atas wilayah kecamatan. Selanjutnya wilayah Kecamatan dibagi lagi atas kelurahan dan desa. Setiap tingkatan wilayah atau daerah memiliki pemerintahannya sendiri. Daerah provinsi memiliki pemerintahan daerah provinsi yang dikepalai oleh Gubernur, daerah kabupaten memiliki pemerintahan daerah kabupaten yang dikepalai oleh Bupati. Daerah kota mempunyai pemerintahan daerah kota yang dikepalai oleh Walikota. Wilayah kecamatan memiliki pemerintahan wilayah kecamatan yang dikepalai oleh Camat. Desa dan kelurahan memiliki pemerintahan desa dan pemerintahan kelurahan yang masing-masling dikepalai oleh Kepala Desa dan Lurah.

Untuk menjaga kepastian hukum, penyelenggaraan urusan pemerintah wajib dilaksanakan menurut hukum. Hukum menjadi dasar keabsahan semua tugas dan wewenang pemerintah. Ini 
merupakan konsekuensi dari Pasal 1 Ayat (3) UUD 1945 yang menyatakan Indonesia adalah negara hukum. Hukum menjadi sangat penting karena diperlukan bagi penyelenggaraan negara dan pemerintahan serta dan semua aspek kehidupan. Karena itu hukum perlu dibuat sesuai dengan kebutuhan hukum negara, pemerintah, dan masyarakat.

Melalui Undang-Undang Nomor 12 Tahun 2011 tentang Pembentukan Peraturan Perundangundangan (UU No. 12 Tahun 2011), negara telah mengatur jenis-jenis peraturan perundangundangan, mulai dari UUD 1945 sampai dengan Peraturan Kepala Desa. Ini menunjukan bahwa pengelolaan kehidupan bernegara, dari tingkat pusat sampai dengan tingkat desa perlu diatur secara hukum. UU No. 12 Tahun 2011 juga mengatur tata cara pembentukan dan teknis penyusunan peraturan perundang-undangan. Tata cara pembentukan tersebut dimulai dari perencanaan pembentukan, penyusunan rancangan, pembahasan rancangan, persetujuan atau penetapan, pengesahan, pengundangan, dan penyebarluasan peraturan perundang-undangan yang dibentuknya. Selain itu, tata cara pembentukan peraturan perundang-undangan juga menyangkut sistematika, kerangka, format, dan teknis penyusunan. Hal-hal tersebut menjadi perhatian bagi pembentukan peraturan, termasuk pembentukan peraturan desa.

Desa adalah suatu kesatuan wilayah yang memiliki pemerintahan terendah, memiliki kedudukan yang sederajat dengan kelurahan, namun keduanya memiliki perbedaan. Perbedaannya adalah terletak pada karakter wilayah dan pemerintahannya. Desa memiliki karakteristik wilyah dan kehidupan yang masih kuat dengan pola tradisional, dan memiliki pemerintahan otonom terkecil dan terendah di wilayah Indonesia. Kelurahan memiliki karakter wilayah perkotaan dan pola kehidupan masyaraakat yang modern serta memiliki pemerintahan yang administratif (Fokusmedia, 2006).

Kabupaten Indramayu adalah salah satu kebupaten di Indonesia, yang lebih banyak memiliki karakteristik pedesaannya. Letaknya berada di Daerah Provinsi Jawa Barat, yang berjarak sekitar $180 \mathrm{~km}$ arah timur dari Daerah Khusus Ibukota Jakarta. Kabupaten ini berada di Pantai Utara (Pantura) Jawa Barat yang berbatasan dengan Kabupaten Subang di sebelah Barat, Kapupaten Sumedang di sebelah selatan, Kabupaten Majalengka di sebelah selatan, Kabupaten Cirebon di sebelah timur, dan pantai utara laut Jawa di sebelah utara. Luas wilayahnya adalah 2.040,11 ha, yang dihuni oleh 31 kecamatan dengan 317 desa di dalamnya.

Dalam rangka melaksanakan urusannya, pemerintah desa mempunyai wewenang mengatur segala usuran desa dengan peraturan desa. Kepala Desa bersama dengan Badan Permusyawaratan Desa (BPD) di Kabupaten Indramayu telah membentuk peraturan desa dalam rangka mengatur dan mengurus urusan desa. Secara hukum, pembentukan peraturan desa oleh pemerintah desa di Kabupaten Indramayu wajib mengacu pada ketentuan dan tata cara pembentukan peraturan perundang-undangan yang telah diatur oleh UU No.12 Tahun 2011. Apakah pembentukan peraturan desa di Kabupaten Indramayu telah mengimplementasikan UU No. 12 Tahun 2011? Kendala apakah yang dihadapi aparatur pemerinahan desa dalam mengimplementasikan UU No. 12 Tahun 2011 pada praktik pembentukan peraturan desa? Kedua permasalahan tersebut sangat menarik untuk diteliti, agar diketahui kesesuaian peraturan desa dengan ketentuan UU No. 12 Tahun 2011, dan mengetahui kendala yang dihadapi aparatur pemerintah desa dalam membentuk peraturana desa.

\section{METODE PENELITIAN}

Kedua masalah di atas telah diteliti dengan menggunakan metode penelitian hukum empiris yang dikobinasikan dengan penelitian hokum normatif. Data yang diteliti adalah praktik pembentukan 
peraturan desa oleh aparatur pemerintah desa yaitu Kepala Desa dan Dewan Permusyawaratan Desa (BPD) dan peraturan desa yang dibentuknya. Sampel datanya adalah pembentukan peraturan desa dan peraturan desa di 16 desa di wilayah Kecamatan Bongas dan Kecamatan Patrol Kabupaten Indramayu. Pengumpulan datanya dilakukan dengan kuesioner terhadap informan pembentuk peraturan desa di 16 desa serta 69 peraturan desa di 16 desa tersebut. Data penelitian ini dianalisis dengan menggunakan pendekatan kualitatif, yang kemudian disimpulkan menjadi hasil peneliitan.

\section{HASIL DAN PEMBAHASAN}

\section{Kewenangan membentuk peraturan desa}

Istilah desa telah muncul sejak adanya masyarakat di pulau Jawa. Penggunaan istilah itu merambah ke daerah lain, seperti Madura, Bali, dan beberapa daerah lain di Indonesia. Beberapa daerah lain menggunakan istilah berbeda selain desa. Misalnya Minangkabau Sumatera Barat menggunakan istilah Nagari, Medan Sumatera Utara menggunakan istilah Marga atau Huta, Aceh menggunakan istilah Gampong, Sulawesi Selatan menggunakan kata Lembang, Kalimantan Selatan dan Papua menggunakan istilah Kampung, dan Maluku menggunakan Negeri (Rasji, 2017).

Berbagai istilah sebagaimana disebutkan di atas, pada pokoknya berkembang bersamaan dengan perkembangan masyarakat. Untuk memudahkan administrasi pemerintahan, Pemerintah Republik Indonesia telah berupaya menyamakan penggunaan istilah desa untuk semua kesatuan masyarakat yang sama di seluruh wilayah Indonesia. Karena itu, pada tahun 1974 legislatif menetapkan Undang-Undang Nomor 5 Tahun 1974 tentang Pemerintahan Di Daerah (UU No. 5 Tahun 1974) yang di dalamnya menggunakan istilah desa. Kemudian desa mendapatkann penguatan peraturannya dengan terbitnya Undang-Undang Nomor 5 Tahun 1979 tentang Desa (UU No. Tahun 1979). Pengaturan desa mengalami pasang surut, dan terakhir desa diatur kembali secara khusus Undang-Undang Nomor 6 Tahun 2014 tentang Desa (UU No. 6 Tahun 12014). UU yang terakhir tidak menyeragamkan penggunaan istilah desa untuk semua satuan pemerintahan terendah di Indonesia. Pasal 1 angka 1 menegaskan bahwa "Desa adalah desa dan desa adat atau yang disebut dengan nama lain, selanjutnya disebut desa, adalah kesatuan masyarakat hukum yang memiliki batas wilayah yang berwenang untuk mengatur dan mengurus urusan pemerintahan, kepentingan masyarakat setempat berdasarkan prakarsa masyarakat, hak asal usul, dan/atau hak tradisional yang diakui dan dihormati dalam sistem pemerintahan Negara Kesatuan Republik Indonesia.

Lebih lanjut Pasal 1 angka 2 UU No. 6 Tahun 2014 menyatakan pemerintahan desa adalah penyelenggaraan urusan pemerintahan oleh pemerintah desa dan Badan Musyawarah Desa dalam mengatur dan mengurus kepentingan masyarakat setempat berdasarkan asal-usul dan adat istiadat setempat yang diakui dan dihormati dalam sistem Pemerintahan Negara Kesatuan Republik Indonesia. Ini berarti pemerintahan desa terdiri dari Pemerintah Desa dan Badan Permusyaratan Desa (BPD) atau sebutan lain. Pemerintah Desa adalah Kepala Desa atau yang disebut dengan nama lain dibantu perangkat desa sebagai unsur penyelenggara pemerintahan desa (Pasal 1 angka 3). BPD atau disebut dengan nama lain adalah lembaga yang melaksanakan fungsi pemerintahan yang anggotanya merupakan wakil dari penduduk desa berdasarkan keterwakilan wilayah dan ditetapkan secara demokratis (Pasal 1 angka 4).

Pemerintah Desa dan BPD, keduanya memiliki wewenang dalam membentuk peraturan desa, meskipun peranan keduanya berbeda. Pemerintah desa bertindak sebagai lembaga eksekutif desa dan BPD sebagai legislatif desa (Anonim, 2011). Legislatif desa dimaksud adalah lembaga 
pembentuk peraturan desa, sedangkan eksekutif desa adalah lembaga yang melaksanakan peraturan desa. Sinergi keduanya melahirkan peraturan desa yang mempunyai dampak penting bagi keberhasilan pembangunan desa untuk mewujudkan kesejahteraan masyarakat desa.

Pemerintahan desa memiliki urusan atau tugas dan kewajiban yang menjadi wewenang pemerintahan terendah atau terkecil di Indonesia. Urusan ini terdiri atas urusan yang bersifat otonom dan yang bersifat pendelegasian dari pemerintah pusat atau pemerintahan di atasnya. Urusan otonomi desa adalah urusan pemerintah yang menjadi hak, wewenang, dan kewajiban daerah untuk mengatur dan mengurus urusannya sendiri sesuai dengan asal-usul dan karakteristik desa masing-masing. Urusan delegasi adalah urusan pemerintahan pusat atau pemerintah di atasnya yang dilimpahkan pelaksanaanya kepada pemerintah desa. Sesuai dengan kedua sifat urusan tersebut, pemerintah desa wajib melaksanakan urusan pemerintah pusat atau pemerintah di atasnya yang didelegasikan kepada desa, dan wajib melaksanakan urusan otonomi yang berasal dari inisiatif masyarakat desa.

Menurut Pasal 69 UU No. 6 Tahun 2014 desa dapat membentuk peraturan desa. Peraturan desa dibentuk dan ditetapkan oleh Kepala Desa setelah dibahas dan disepakati bersama dengan BPD. BPD adalah lembaga yang mewakili penduduk desa dalam melaksanakan fungsi pemerintahan desa, yang salah satunya adalah fungsi dalam membentuk Peraturan Desa. Hal ini seperti dinyatakan oleh Pasal 55 bahwa BPD mempunyai fungsi membahas dan menyepakati rancangan peraturan desa bersama kepala desa, dan menampung serta menyalurkan aspirasi masyarakat desa.

Proses pembentukan peraturan desa meliputi penyusunan rancangan, pembahasan, pengesahan, dan pengundangan peraturan desa. Rancangan peraturan desa dapat dibuat oleh kepala desa atau BPD. Rancangan peraturan desa dibahas bersama-sama antara kepala desa dan BPD untuk mendapatkan persetujuan atau kesepakatan bersama. Rancangan peraturan desa yang sudah mendapatkan persetujuan bersama kepala desa dan BPD disahkan oleh kepala desa menjadi peraturan desa. Peraturan desa yang sudah disahkan diundangkan ke dalam lembaran desa. Dengan demikian, peraturan desa berhasil dibentuk dan mempunyai kekuatan berlaku mengikat.

\section{Praktik pembentukan peraturan desa}

Sesuai dengan sampel penelitian, penelitian praktik pembentukan peraturan desa diakukan di desa-desa di Kecamatan Bongas dan Kecamatan Patrol Kbupaten Indramayu. Kecamatan Bongas membawahi 8 desa dan Kecamatan Patrol juga membawahi 8 desa, sehingga semuanya berjumlah 16 desa. Semua desa memandang bahwa peraturan desa merupakan instrumen penting dan strategis yang dapat digunakan oleh pemerintah desa. Karena itu semua desa sudah membuat peraturan desa meskipun jumlahnya relatif sedikit. Dari 16 desa yang ada di dua kecamatan tersebut terlihat data peraturan desa yang dibuat dalam waktu lima tahun terakhir adalah sebagaimana tercantum pada tabel 1 di bawah ini.

Tabel 1. Data Peraturan Desa

\begin{tabular}{clclc}
\hline & \multicolumn{2}{c}{ Kecamatan Bongas } & Jumlah & \multicolumn{2}{c}{ Kecamatan Patrol } \\
No. & \multicolumn{1}{c}{ Nama Desa } & Peraturan Desa & \multicolumn{1}{c}{ Nama Desa } & $\begin{array}{c}\text { Jumlah } \\
\text { Peraturan Desa }\end{array}$ \\
\hline 1 & Desa Bongas & 4 & Desa Patrol & 5 \\
\hline 2 & Desa Sidamulya & 3 & Desa Patrol Lor & 5 \\
\hline 3 & Desa Margamulya & 5 & Desa Patrol Baru & 5 \\
\hline 4 & Desa Cipedang & 4 & Desa Bugel & 3 \\
\hline 5 & Desa Kertajaya & 4 & Desa Arjasari & 4 \\
\hline
\end{tabular}




\begin{tabular}{clclc}
\hline 6 & Desa Cipaat & 3 & Desa Mekarsari & 5 \\
\hline 7 & Desa Kertamulya & 5 & Desa Limpas & 7 \\
\hline 8 & Desa Plawangan & 3 & Desa Sikahaji & 4 \\
\hline & Jumlah & 31 & Jumlah & 38 \\
\hline
\end{tabular}

Data di atas memperlihatkan bahwa pemerintah desa telah mempraktikan pembuatan peraturan desa, mekipun jumlahnya relatif tidak banyak. Jumlah peraturan desa yang dibentuk oleh pemerintah desa di wilayah Kecamatan Bongas berjumlah 31 peraturan desa sedangkan yang dibuat oleh pemerintah desa di wilayah kecamatan Patrol sebanyak 38 peraturan desa. Pemerintah desa di wilayah Kecamatan Patrol lebih banyak mempraktikan pembuatan peraturan desa daripada pemerintah desa di wilayah Kecamatan Bongas.

Jumlah peraturan desa di atas menunjukan tingkat kebutuhan pemerintah desa dalam mengatur urusan pemerintahan desa berbeda-beda, karena tingkat kebutuhan hukumnya untuk mengatur semua urusan pemerintahanpun berbeda. Meskipun demikian, perbedaan jumlah peraturan desa tidak menunjukan tinggi atau rendahnya tingkat kemampuan pemerintah desa dalam membentuk peraturan desa.

Pemerintah Daerah Kabupaten Indramayu telah menetapkan Peraturan Daerah Kabupeten Indramayu Nomor 5 Tahun 2018 tentang Produk Hukum Desa (Perda No. 5 Tahun 2018), yang merupakan implementasi dari UU No. 12 Tahun 2011. Menurut Menurut Pasal 8 UU No. 12 Tahun 2011 jo Pasal 5 Perda tersebut peraturan desa dibentuk oleh kepala desa (Kuwu) dan Badan Permusyawaratan Desa (BPD). Meskipun demikian menurut Pasal 6 dan Pasal 7 Perda di atas rancangan peraturan desa (Raperdes) dapat dibuat dan diajukan oleh kepala desa atau oleh BPD. Raperdes dibahas bersama oleh kepala desa dan BPD untuk mendapatkan persetujuaan bersama. Raperdes yang telah mendapatkan persetujuan bersama tersebut disahkan oleh kepala desa menjadi peraturan desa.

Pada praktik pembuatan peraturan desa ditemukan bahwa Raperdes lebih banyak dibuat oleh kepala desa, bahkan hampir tidak ada Raperdes yang dibuat dan diajukan oleh BPD. Alasannya adalah pemerintah desa yang lebih mengetahui permasalahan dan kebutuhan hukumnya. Bahkan ada Raperdes tanpa dibahas bersama atau melibatkan atau persetujuan bersama BPD. Kepala desa, yang di Kabupaten Indramayu disebut Kuwu, menyusun Raperdes bersama perangkat desa, yang di Kabupaten Indramayu disebut pamong desa.

Pada tahap pembahasan Raperdes, kepala desa dan BPD tidak selalu melakukan pembahasan bersama secara mendalam. Pembahasan dengan BPD lebih banyak dilakukan secara formalitas, yaitu Raperda yang sudah dibahas secara final oleh kepala desa dan pamong desa, kemudian tinggal ditandatangani oleh BPD. BPD lebih banyak tinggal menandatangani persetujuan Raperdes, berita acara pembahasan Raperdes, dan menyatakan setuju Raperdes menjadi Perdes. Dari 16 desa yang berada di dua wilayah kecamatan di atas, hanya pembuatan peraturan desa tentang Anggaran Pendapatan dan Belanja Desa (APBDes) yang selalu melibatkan BPD secara mendalam dan mendapatkan persetujuan bersama kepala desa dan BPD. Untuk pembuatan peraturan desa tentang urusan pemerintahan desa lainya, hanya ada enam desa yang banyak melibatkan BPD yaitu Desa Margamulya, Desa Kertamulya, Desa Plawangan, Desa Patrol Baru, Desa Patrol Lor, dan Desa Bugel. Meskipun demikian, keterlibatan BPD lebih banyak menerima rancangan dan menyetujui rancangan peraturan desa yang disampaikan oleh kepala desa, namun hal ini tidak menimbulkan permasalahan bagi kepala desa dan BPD dalam pembentukan peraturan desa. Raperdes tersebut kemudian disahkan oleh kepala desa (kuwu) menjadi peraturan desa. 
Praktik di atas cukup diterima oleh semua pihak di pemerintahan desa. BPD yang memiliki kekuasaan untuk membentuk peraturan desa bersama dengan kepala desa tidak menggunakan kekuasaannya secara baik. Bahkan tampaknya BPD tidak mempersoalkan apapun mengenai pembentukan peraturan desa tersebut, sehingga meskipun peraturan desa itu sebagian banyak hanya dibentuk oleh kepala desa, tetap diakui sebagai peraturan yang sah.

Secara material, praktik pembuatan peraturan desa tidak sesuai dengan UU No. 12 Tahun 2011 dan Perda No. 5 Tahun 2018. Hak inisiatif BPD dalam membentuk Raperdes tidak pernah digunakan oleh BPD, pembahasan Raperdes tidak dilaksanakan sebagaimana mestinya, dan persetujuan BPD terhadap Raperdes hanya bersifat formalitas. Meskipun demikian, secara normal, pembentukan peraturan desa telah mendapatkan persetujuan bersama kepala desa dan BPD.

UU No. 12 Tahun 2011 dan Perda No. 5 Tahun 2018 telah mengatur aspek teknis pembentukan peraturan desa. Aspek teknis ini mencakup sistematika (kerangka) dan perumusan substansinya. Sistematika (kerangka) peraturan desa meliputi empat bagian yaitu bagian judul, bagian pembukaan, bagian batang tubuh, dan bagian penutup. Apabila diperlukan, peraturan desa dapat dilengkapi dengan penjelasan dan/atau lampiran. Kedua peraturan di atas telah mengatur secara teknis bagian-bagian peraturan desa, sehingga kepala desa dan BPD tinggal menerapkannya pada pembentukan peraturan desa.

Praktik pembentukan peraturan desa oleh pemerintahan desa di kedua wilayah kecamatan di atas telah memenuhi sistematika peraturan perundang-undangan menurut UU No. 12 Tahun 2011 dan Perda No. 5 Tahun 2018. Peraturan desa telah mencakup bagian judul, bagian pembukaan, bagian batang tubuh, dan bagian penutup. Meskipun demikian, teknis penyusunan pada bagianbagian tersebut masih menjadi permasalahan. Akibatnya peraturan desa yang dibentuk banyak yang belum memenuhi persyaratan teknik penyusunan peraturan perundang-undangan yang diatur di dalam UU No. 12 Tahun 2011 dan Perda di atas. Masalah-masalah dimaksud adalah sebagaimana diuraikan pada uraian di bawah ini.

Pada bagian judul, hampir semua peraturan desa memenuhi teknis penyusunan bagian judul, yang menuliskan jenis peraturan desa, nomor dan tahun pembentukan, dan nama peraturan desa. Tata tulisnya sudah menggunakan huruf kapital, urutan subsub bagian telah sesuai ketentuan, serta posisinya ditulis senter, seperti pada contoh di bawah. Namun pada penulisan jenis peraturan desa kurang dilengkapi dengan penulisan nama kecamatan dan nama kabupaten. Dari contoh di atas,

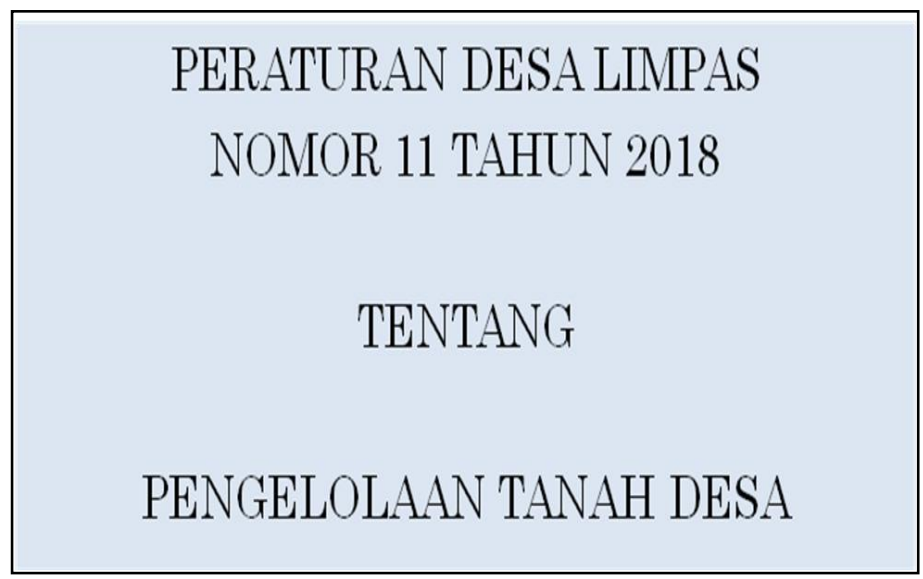
seharusya ditulis "PERATURAN DESA LIMPAS KECAMATAN PATROL KABUPATEN INDRAMAYU". Selain itu, penulisan jarak baris antara "NOMOR 11 TAHUN 2018" dan "tentang" serta antara "TENTANG" dan "PENGELOLAAN TANAH DESA" harus sama jaraknya seperti antara penulisan 'PERATURAN DESA LIMPAS" dan penulisan'NOMOR 11 TAHUN 2018. 
Teknis penulisan bagian pembukaan masih menjadi masalah dan belum semua pemerintah desa mampu merumuskannya dengan baik dan benar. Misalnya tampak pada contoh di bawah ini. Penulisan frase "DENGAN RAHMAT TUHAN YANG MAHA ESA" dan jabatan pembentuk peraturan desa yang diakhiri dengan tanda baca koma, ditulis dengan huruf kapital, penempatan penulisan jabatan pembentuk peraturaan desa di bawah frase tersebut, dan diletakan pada posisi senter adalah benar. Teknis penulisan pertimbangan sudah benar namun pada pertimbangan terakhir seharusnya ditulis “...perlu ditetapkan Peraturan Desa tentang Pengelolaan Tanah Desa" yang diakhiri tanda baca titik koma (;). Selain itu rumusan pertimbangan filosofi, sosiologi, dan yuridis belum banyak ditulis dengan benar.

DENGAN RAHMAT TUHAN YANG MAHA ESA KUWU LIMPAS,

Menimbang : a. bahwa Tanah Kas Desa merupakan salah satu kekayaan desa yang harus dijaga dan dimanfaatkan sepenuhnya untuk kepentingan penyelenggaraan pemerintahan, pembangunan, dan kemasyarakatan dalam rangka meningkatkan kesejahteraan masyarakat desa;

b. bahwa rencana penertiban Pengelolaan Tanah Kas Desa telah mendapat persetujuan dalam musyawarah desa;

c. bahwa berdasarkan pertimbangan sebagaimana dimaksud pada huruf a dan b maka perlu ditetapkan dengan Peraturan Desa.

Pada teknis penulisan dasar hukum adalah sudah benar, yang diawali dengan kata "Mengingat" dan diakhiri dengan titik dua (:), yang dilanjutkan dengan penulisan dasar hukum yang diurutkan dengan menggunakan angka. Setiap penulisan dasar hukum diakhiri dengan tanda baca titik koma (;). Kesalahan yang masih terjadi adalah menuliskan dasar hukum yang sudah tidak berlaku, masih ada penulisan tanda baca titik (.) di akhir dasar hukum padahal seharusnya ditulis tanda titik koma (;). Selain itu, dasar hukum yang ditulis terlalu tinggi, yang seharusnya cukup mulai dari peraturan Daerah Kabupaten Indramayu. Beberapa kesalahan dimaksud dapat dilihat pada contoh bagian peraturan desa di bawah ini. 


\begin{tabular}{|c|c|}
\hline gat & 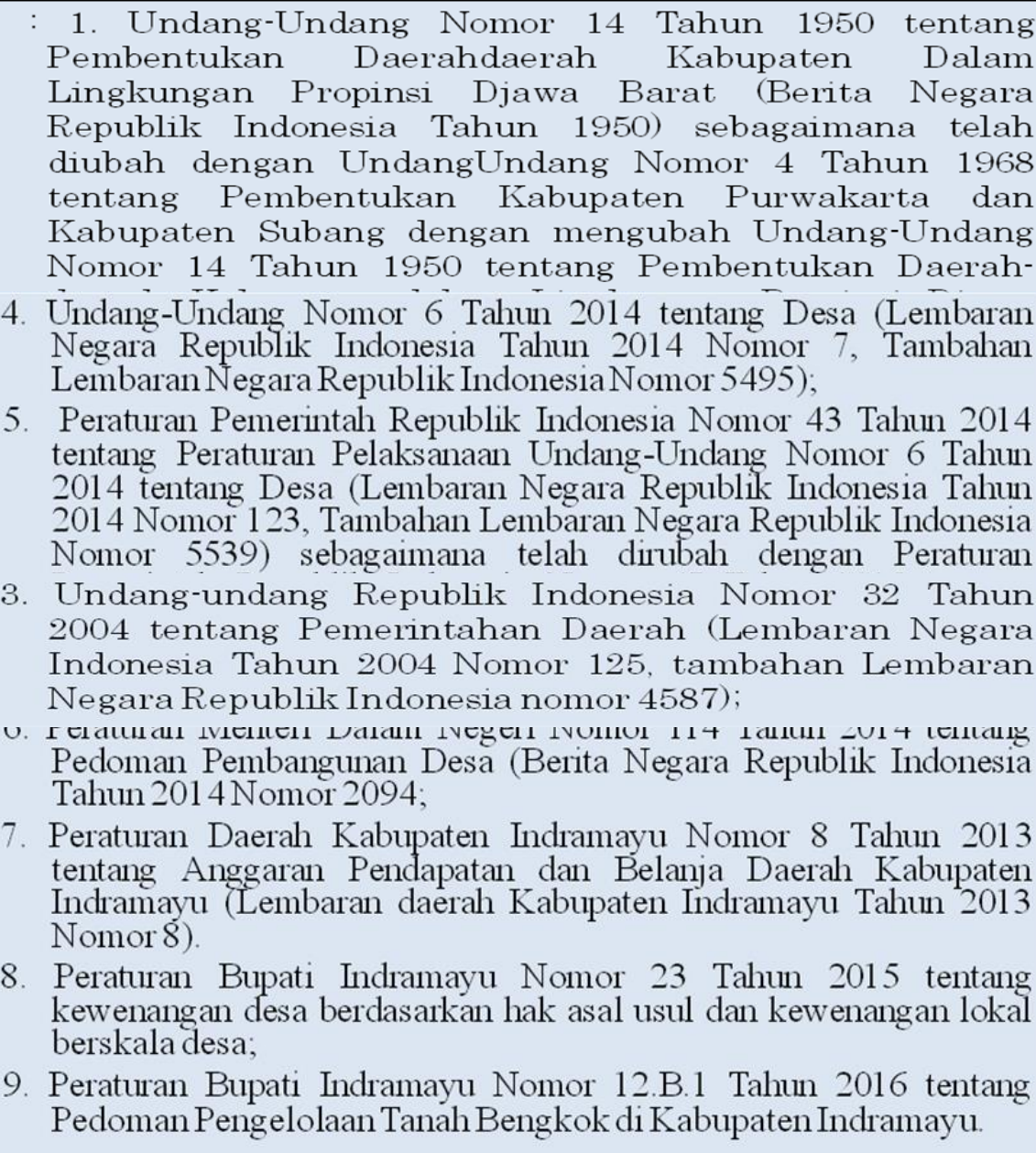 \\
\hline
\end{tabular}


Kesalahan lain adalah pada bagian pembukaan, yaitu adanya penulisan kata "memperhatikan" setelah penulisan dasar hukum sebagai bagian dari bagian pembukaan. Sebenarnya materi "memperhatikan", seperti pada contoh di atas, merupakan pertimbangan $\begin{array}{ll}\text { Memperhatikan: } & \text { Musyawarah Badan Permusyawaratan Desa Limpas } \\ & \text { Kecamatan Patrol tentang Tata Cara Pengelolaan Tanah Kas } \\ & \text { Desa. }\end{array}$

pemikiran dari pembentuk peraturan. Apabila terdapat substansi yang menjadi perhatian pembentuk peraturan desa maka seharusnya materi yang menjadi perhatian tersebut ditulis pada sub-bagian pertimbangan. Karena itu, adanya penulisan kata "perhatian" pada bagian pembukaan peraturan desa adalah tidak sesuai dengan UU No. 12 Tahun 2011 dan Perda No. 5 Tahun 2018.

Pada perumusan bagian persetujuan bersama antara BPD dan kepala desa, secara redaksional penulisan kalimat dan subtansinya sudah benar. Demikian juga tata letak perumusannya juga telah benar, yaitu pada posisi tengah margin. Namun rumusan bagian ini masih terdapat kesalahan, yaitu penulisan frase "DENGAN PERSETUJUAN BERSAMA" dan penulisan kata "DAN" yang ditulis dengan hukuf kapital. Hal ini tampak pada contoh penulisan persetujuan bersama Peraturan Desa No. 11 Tahun 2018 seperti di bawah ini, yang seharusnya "Dengan Bersama" ditulis

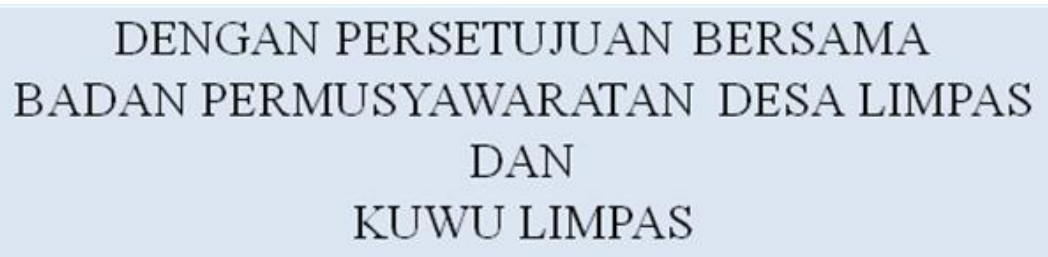$$
\text { DENGAN PERSETUJUAN BERSAMA }
$$$$
\text { BADAN PERMUSYAWARATAN DESA LIMPAS }
$$$$
\text { DAN }
$$$$
\text { KUWU LIMPAS }
$$

menggunkan huruf kecil

serta kata "DAN" ditulis "dan" dengan menggunakan huruf kecil.

Pada sub-bagian diktum juga masih terdapat kesalahan. Hal itu tampak pada contoh Peraturan Desa Limpas No. 11 Tahun 2018 di bawah ini. Sub-bagian diktum adalah sub-bagian yang merumuskan keputusan, dengan cara menuliskan kata "memutuskan", "menetapkan", dan menuliskan kalimat nama peraturan desa. Pada contoh di samping, penulisan kata dan tata letak "MEMUTUSKAN"

adalah benar, namun penulisan tanda baca titik dua (:) seharusnya tidak diberi spasi, karena harus \begin{tabular}{c} 
MEMUTUSKAN : \\
Menetapkan : TATA CARA PENGELOLAANTANAHDESA \\
\hline
\end{tabular} menempel pada bagian akhir kata tersebut. Penulisan kata "Menetapkan" adalah sudah benar, namun penulisan tanda baca titik dua (:) seharusnya tidak diberi spasi melainkan menempel pada bagian akhir kata tersebut. Kemudian penulisan nama peraturan desa masih terdapat kekurangan karena tidak terdapat tulisan "PERATURAN DESA TENTANG" dan tidak diakhiri tanda baca titik (.). Penulisan diktum nama peraturan desa yang benar adalah "PERATURAN DESA TENTANG TATA KELOLA TANAH DESA.” yang diakhiri tanda baca titik (.).

Bagian selanjutnya adalah bagian batang tubuh, yang di dalamnya meliputi ketentuan umum, ketentuan materi pokok, ketentuan pidana, ketentuan peralihan, dan ketentuan penutup. Secara umum, peraturan desa telah merumuskan bagian ini cukup baik. Beberapa kesalahan yang masih terjadi adalah sebagai berikut.

1) Rumusan materi muatan pada pasal, ayat, atau butir banyak yang tidak memenuhi unsur norma. Setiap norma berisi addessat (orang/lembaga) yang dituju dan hal yang diatur (perbuatan). Hal ini tampak pada contoh rumusan norma pasal berikut. 


\section{Pasal 2}

(1) Tanah Desa dikelola berdasarkan azas transparan, akuntabel, serta dilakukan dengan tertib dan disiplin anggaran;

(2) Pengelolaan Tanah Kas Desa sebagaimana dimaksud pada pasal 2 ayat 1 dilakukan selama masa jabatan kuwu.

Pada contoh di atas tidak terdapat sasaran/alamat orang yang dituju, yang seharunsya dituliskan sasarannya. Selain itu rumusan Ayat (1) diakhiri dengan penulisan tanda baca yang salah yaitu titik koma (;), yang seharusnya ditulis dengan tanda baca titik (.).

2) Penulisan butir-butir dari ketentuan pasal atau ayat, yang seharusnya menggunakan huruf tetapi ditulis menggunakan angka ayat. Hal ini terlihat pada contoh berikut.

\section{Pasal 3}

Tanah Kas Desa terdiri dari:

(1) Tanah Titisara;

(2) Tanah Bengkok.

Seharusnya pasal tersebut ditulis sebagai berikut.

\begin{tabular}{ll|} 
& Pasal 3 \\
Tanah Kas Desa terdiri dari: & \\
a. Tanah Titisara; & \\
b. Tanah Bengkok.
\end{tabular}

3) Penulisan nomor ayat tidak konsisten karena ada yang menggunakan (1) dan 1, yang seharusnya ditulis (1). Selain itu penulisan rumusan ayat atau rumusan norma banyak yang menggunakan tanda baca titik koma (;), yang seharusnya menggunakan tanda baca titik (.). Hal ini seperti pada contoh berikut.

\section{Pasal 4}

(1) Hasil Pengelolaan Tanah Kas Desa sebagaimana dimaksud pada ayat 1 dan 2 dimaksud pada APBDes setiap tahun berjalan sebagai sumber pendapatan asli desa;

(2) Hasil Lelang Sewa Tanah Kas Desa sebagaimana dimaksud pada pasal 3 ayat 1 dan 2 diperuntukan sebagai Tambahan Tunjangan/Penghasilan Kuwu dan perangkat desa serta dipergunakan untuk penyelenggaraan Pemerintahan Desa, pembangunan, pembinaan, dan pemberdayaan masyarakat; 
4) Penulisan huruf besar (kapital) dan huruf kecil tidak konsisten dan tidak tepat sesuai ketentuan. Hal ini seperti pada penulisan sebagai berikut.

$$
\begin{gathered}
\text { Pasal 1 } \\
\text { Dalam Peaturan Desa ini Yang dimaksud dengan: }
\end{gathered}
$$

Pada contoh di atas, kata "Yang" seharusnya ditulis dengan huruf "yang".

Pada bagian penutup peraturan desa masih terdapat kesalahan perumusan dan penulisan tanda baca. Hal ini tampak pada contoh rumusan norma berikut.

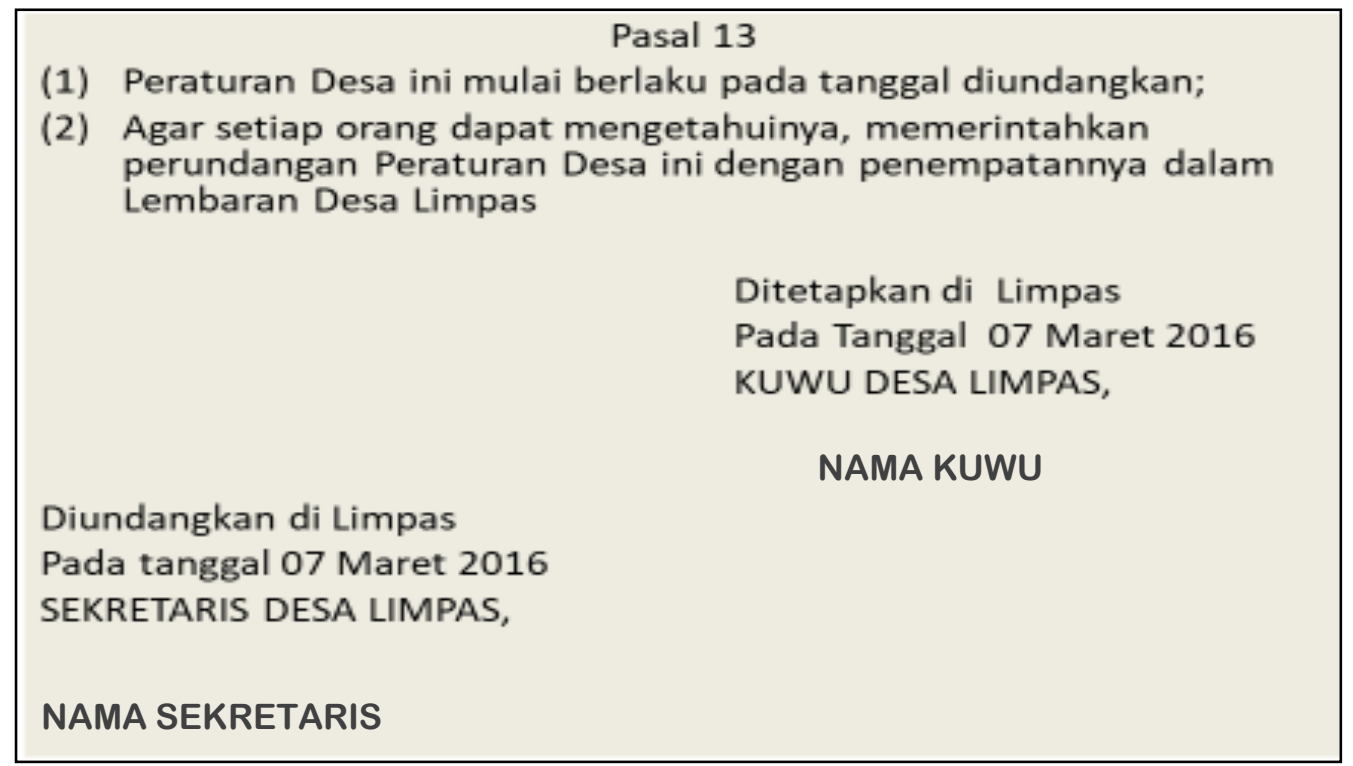

Pada contoh di atas terdapat kesalahan penulisan Ayat (2). Kalimat yang ditulis dengan Ayat (2) adalah rumusan perintah pengundangan, yang seharusnya tidak dirumuskan ke dalam ayat. Karena itu seharusnya Pasal 13 hanya berisi satu norma yang tidak dirumuskan ke dalam ayat.

Pada rumusan pengesahan dan pengundangan tidak dirumuskan secara konsisten, karena seharusnya pada rumusan tempat dan tanggal pengesahan tidak perlu diberi tulisan tanda baca. Penulisan pejabat pembentuk Peraturan Desa Limpas seharusnya menggunakan huruf kapital yang diakhiri tanda baca koma (,). Demikian juga penulisan pejabat yang mengundangkan peraturan desa diakhiri tanda baca koma (,). Berdasarkan catatan koreksi tersebut, maka seharusnya rumusan bagian penutup di atas ditulis sebagai berikut. 


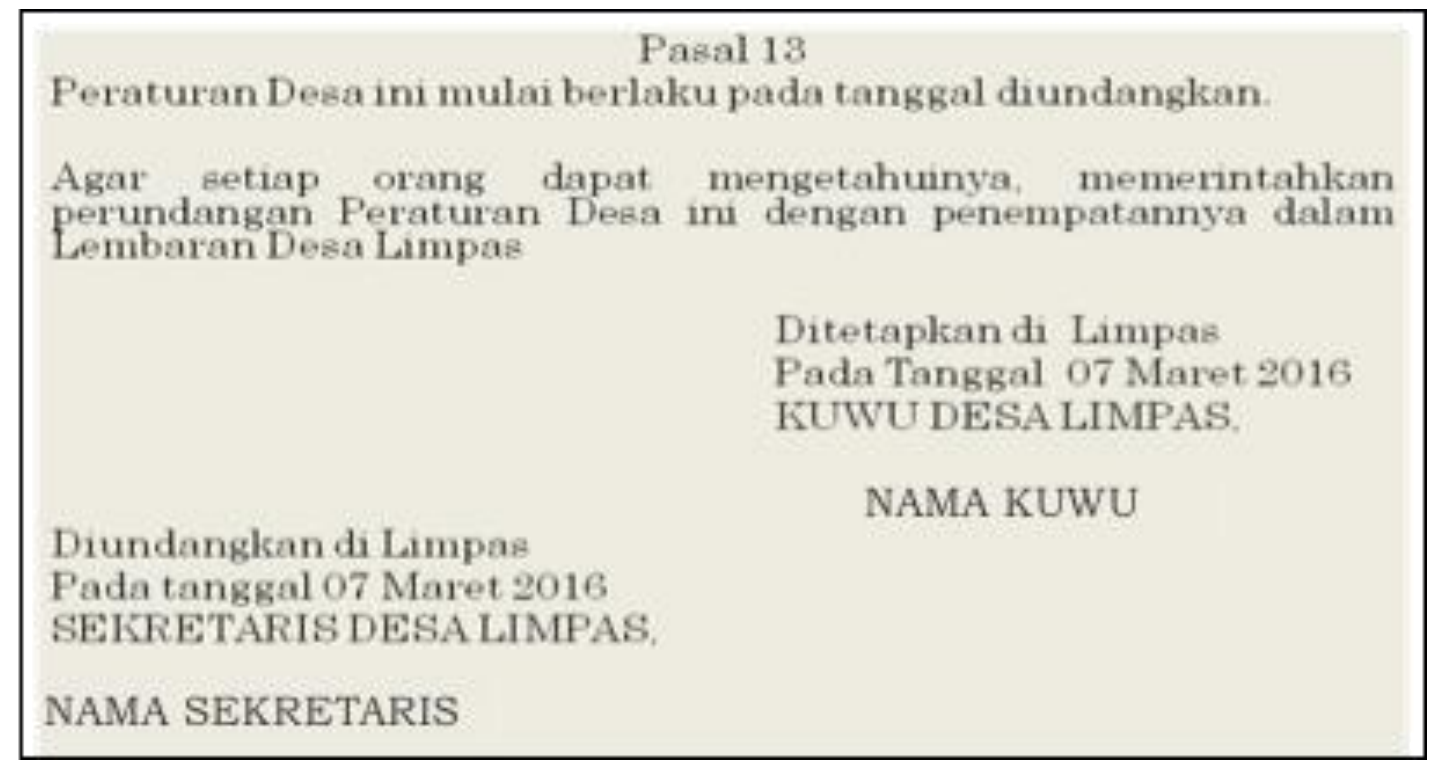

Pada bagian akhir dari bagian penutup terdapat penulisan lembaran desa, tahun lembaran desa, dan nomor lembaran desa. Namun peraturan desa di kedua wilayah kecamatan di atas penulisan lembara desa tidak konsisten. Padahal seharusnya ditulis secara konsisten seperti contoh "LEMBARAN DESA LIMPAS TAHUN 2018 NOMOR 11".

Beberapa kesalahan pada praktik pembentukan peraturan desa membuktikan bahwa penerapan UU No. 12 Tahun 2011 pada pembentukan peraturan desa belum berjalan dengan baik. Hal tersebut dipengaruhi oleh kurangnya pengetahuan dan kemampuan aparatur pemerintahan desa dalam membentuk peraturan desa. Hal ini tampak dari tabel 2 hasil penelitian sebagai berikut.

Tabel 2. Sumber Pemahaman Aparatur Pemerintahan Desa Untuk Membentuk Peraturan Desa

\begin{tabular}{clcc}
\hline No. & \multicolumn{1}{c}{ SUMBER PEMAHAMAN } & YA & TIDAK \\
\hline 1 & $\begin{array}{l}\text { Pernah belajar peraturan perundang-undangan di } \\
\text { sekolah atau perguruan Tinggi }\end{array}$ & $8=10,00 \%$ & $72=90,00 \%$ \\
\hline 2 & $\begin{array}{l}\text { Pernah belajar peraturan perundang-undangan di } \\
\text { kursus/pelatihan/bimbingan }\end{array}$ & $21=26.00 \%$ & $59=74,00 \%$ \\
\hline 3 & $\begin{array}{l}\text { Pernah belajar peraturan peraturan perundang- } \\
\text { undangan dari internat }\end{array}$ & $48=60,00 \%$ & $32=40,00 \%$ \\
\hline 4 & $\begin{array}{l}\text { Pernah belajar peraturan perundang-undangan dari } \\
\text { teman/atasan }\end{array}$ & $42=52,00 \%$ & $38=48,00 \%$ \\
\hline 5 & Pernah membuat peraturan desa & $53=66,00 \%$ & $27=34,00 \%$
\end{tabular}

Data di atas memperlihatkan bahwa sebagian besar aparatur pemerintah desa tidak pernah belajar ilmu dan peraturan perundang-undangan melalui pendidikan formal (sekolah dan/atau perguruan tinggi) atau pendidikan non formal (kursus/pelatihan/bimbingan). Ini menunjukan aparatur pemerintahan desa belum memahami UU No. 12 Tahun 2011, sehingga aparatur pemerintahan desa sangat kurang mampu membentuk peraturan desa sesuai dengan UU No. 12 Tahun 2011. Inilah yang menjadi kendala besar aparatur pemerintahan desa dalam membentuk peraturan desa. Data di atas juga memperlihatkan aparatur pemerintahan desa banyak memperoleh pengetahuan tentang pembentukan peraturan desa dari internet, belajar dari teman/atasan saat ikut membentuk 
peraturan desa, dan karena pernah/berpengalaman membentuk peraturan desa. Sumber-sumber pengetahuan ini tidak memberikan petunjuk dan ketentuan yang benar, karena tidak mengajarkan ketentuan yang jelas dan benar. Akibatnya aparatur pemerintahan desa masih mengalami kelulitan bahkan kesalahan dalam pembentukan peraturan desa.

\section{KESIMPULAN DAN SARAN}

Pemerintah desa di Kecamatan Bongas dan Kecamatan Patrol telah membentuk peraturan desa. Peraturan desa yang dibentuknya masih banyak aspek yang tidak sesuai dengan ketentuan yang diatur di dalam UU No. 12 Tahun 2011. Aparatur pemerintahan desa masih banyak melakukan kesalahan dalam membentuk peraturan. Kesalahan tersebut menyangkut format, teknis penyusunan, dan teknis penulisan. Kesalahan-kesalahan pada pembentukan peraturan desa disebabkan oleh kendala rendahnya kemampuan aparatur pemerintahan desa. Aparatur pemerintahan desa tidak pernah mendapatkan pengetahuan tentang pembentukan peraturan perundang-undangan, khususnya pembentukan peraturan desa dari pendidikan formal atau informal. Selama ini pembentukan peraturan desa hanya melihat contoh-contoh yang ada di internet.

Implementasi UU No. 12 Tahun 2018 adalah suatu keharusan, apabila aparatur pemerintah desa ingin membentuk peraturan desa dengan baik dan benar. Pengetahuan dari internet dan bantuan teman belum dapat membantu aparatur pemerintahan desa dalam membentuk peraturan desa dengan baik dan benar. Karena itu, sebaiknya aparatur pemerintah desa atau pemerintah kecamatan melakukan pelatihan atau bimbingan teknis implementasi UU No. 12 Tahun 2011, dengan melibatkan dosen-dosen ilmu perundang-undangan sebagai nara sumber.

Selain itu, sebaiknya pemerintah desa menyelenggarakan workshop pembentukan peraturan desa agar memiliki pengetahuan dan keterampilan pembentukan peraturan desa. Hal ini penting mengingat peraturan desa diperlukan oleh pemerintah desa dalam melaksanakan tugas dan kewajibannya. Melalui kegiatan ini, aparatur pemerintah desa akan dipandu dan dibimbing dalam praktik penyusun kedua peraturan tersebut.

\section{Ucapan Terima Kasih (Acknowledgement)}

Peneliti mengucapkan terima kasih kepada semua pihak yang telah mendukung dan terlibat selama pelaksanaan penelitian ini, sehingga penelitian ini dapat berjalan dan diselesaikan dengan lancar.

\section{REFERENSI}

Anonim. (2011, Januari 29). Dampak pemilihan kepala desa dan masalahnya. Kompas.

Fokusmedia (ed.). (2006). Peraturan pelaksanaan dan administrasi pemerintahan desa dan kelurahan. Bandung: Fokusmedia.

Indonesia. 1945. Undang-Undang Dasar Negara Kesatuan Republik Indonesia Tahun 1945.

Rasji. (2017). Pelaksanaan pemilihan Kuwu di Kabupaten Indramayu Provinsi Jawa Barat (Laporan Hasil Penelitian). Jakarta, FH-LPPM, Universitas Tarumanagara.

. Undang-Undang Nomor 32 Tahun 2004 tentang Pemerintahan Daerah, (Lembaran Negara Republik Indonesia Tahun 2004 Nomor 125, Tambahan Lembaran Negara Republik Indonesia Nomor 4437).

. Undang-Undang Nomor 12 Tahun 2011 tentang Pembentukan Peraturan Perunangundangan.

. Undang-Undang Nomor 6 Tahun 2014 tentang Desa. 
Peraturan Penteri Dalam Negeri Nomor 111 Tahun 2014 tentang Pedoman Peraturan Tingkat Desa. 